\title{
TRANSPARENCY OF AUDIT FIRMS: ANALYSIS OF TRANSPARENCY REPORTS IN TURKEY
}

\author{
Evren Dilek Sengur \\ School of Management, Istanbul University, Turkey
}

\begin{abstract}
Transparency may improve audit quality. In order to increase transparency of audit firms, regulators require audit firms to issue a transparency report. In this regard, the Eighth EU Directive requires audit firms to publish annual transparency reports. In Turkey Independent Audit By-Law has requirements similar to those contained in Article 40 of the EU Directive. The paper examines contents of 2017 transparency reports of audit firms in Turkey. The paper assesses the level of audit firms compliance with requirements of transparent reporting set by the By-Law. The sample of the study consists of 88 transparency reports of audit firms that conducted audit of public interest entities (PIEs) in 2016 in Turkey.
\end{abstract}

Keywords: Transparency report, audit firms, Turkey, KGK

DOI: $10.7176 /$ RJFA/10-8-22

Publication date: April $30^{\text {th }} 2019$

\section{Introduction}

In the aftermath of corporate scandals in the beginning of the twenty-first century audit quality has become a top priority for regulators. Accordingly, it also became an important research topic for academics. One way to enhance audit quality would be to increase transparency with regard to the governance and professional practices of audit firms. Regulators argue that greater transparency of audit firms' internal governance helps to reduce information asymmetry between audit firms and market participants, maintain high-quality audit service and, therefore, maintain the stability of the capital market (Deumes, Schelleman \& Vanstraelen, 2012) .

The Eighth EU Directive requires statutory auditors and audit firms to publish annual transparency reports. In Turkey, Independent Audit By-Law has requirements similar to those contained in Article 40 of the EU Directive.

This paper analyses content of 2017 transparency reports of audit firms in Turkey. The paper assesses the level of audit firm compliance with requirements of transparent reporting set by the By-Law. The sample of the study consists of transparency reports of audit firms that conducted audit of public interest entities (PIEs) in 2016 in Turkey.

The remainder of this paper is structured as follows. The next section provides a literature review in transparency reporting. The third section make explanations about international legislations regarding transparency of audit firms. The fourth section describes emprical findings concerning analysis of content of the transparency reports. Finally, the paper ends with concluding remarks.

\section{Literature Review}

Pott, Mock and Watrin (2008) conducted a survey in order to investigate how practitioners assess several aspects of a transparency report on auditor independence published by auditing firms. The results of the study indicate that the most important safeguards related to auditor independence are perceived to be quality assurance, internal quality controls and independence practice and compliance.

Pivac \& Cular (2012) find out whether there is a significant difference in transparency between the big four audit firms and others in Crotia. The results of the study indicate that regardless the size of audit firms or the membership to big four, audit firms are not fully transparent in Crotia. 
Colar (2014) examines transparency of audit firms that audited financial statements of listed companies, for year 2011 and 2012. The results demonstrate that transparency of audit firms in 2012 has improved significantly, compared with transparency in 2011.

Yi Fu, Elizabeth and Roger (2015) review and summarise the content of 2013 transparency reports of 21 Australian audit firms. The authors find that audit firms meet the minimum transparency report disclosure requirements.

Amirul et al. (2015) examines the awareness and the level of compliance of Malaysian audit firms to the Code of Audit Firm Govenrnace (CAFG) issued by the Financial Reporting Council of United Kingdom. They have concluded that out of 30 audit firms $\% 26,7$ provide transparency report that consist information on the governance structures, management team, duties and decision they made.

Cular (2017) investiates determinants of transparency report delay of audit firms who audited Croatian listed companies in 2015. The results show that the transparency report delay is shorter when audit firms have a greater number of certified auditors.

Girdhar \& Jeppesen (2019) examine the transparency reports published by the Big 4 public accounting firms in the UK, Germany and Denmark. Content of transparency reports is analyzed and semi-structured interviews are conducted with key people from the Big 4 firms who are responsible for developing the transparency reports. The findings show that the content of transparency reports is inconsistent and the transparency reporting practice is not uniform within the Big 4 networks.

\section{Transparency of Audit Firms}

The 8th Company Law Directive on statutory audits was adopted by the European Union (EU) in 2006. The Eighth EU Directive, requires statutory auditors of Public Interest Entities (PIEs) to publish, annual transparency reports as of June 2008. Article 40 of the Directive sets forth certain disclosure requirements related to following elements (European Union, 2006):

a. A description of the legal structure and ownership;

b. Where the audit firm belongs to a network, a description of the network and the legal and structural arrangement in the network;

c. A description of the governance structure of the audit firm;

d. A description of the internal quality control system of the audit firm and a statement by the administrative or management body on the effectiveness of its functioning;

e. An indication of when the last quality assurance review took place;

f. A list of public interest entities for which the audit firm has carried out statutory audits during the preceding financial year;

g. A statement concerning the audit firm's independence practices, which also confirms that an internal review of independence compliance has been conducted;

h. A statement on the policy followed by the audit firm concerning the continuing education of statutory auditors;

i.Financial information showing the importance of the audit firm, such as the total turnover divided into fees from the statutory audit of annual and consolidated accounts, and fees charged for other assurance services, tax advisory services and other non-audit services;

j. Information concerning the basis for the partners' remuneration.

The Australian Corporations Legislation Amendment (Audit Enhancement) Act 2012 requires transparency reports to be prepared by those Australian audit firms which have provided audit services to ten or more significant entities.

According to the Article 17a. Croatian Amended Audit Act (NN, 139/08), audit firms and independent auditors that perform the audits of public interest companies are obliged to publish annual transparency report.

In Turkey Independent Audit By-Law was published on December 26, 2012 and regulates the principles and procedures related with independent audit, independent auditors and independent audit firms. Independent Audit By-Law requires transparency reports to be prepared by those Turkish audit firms which have provided audit audit 
services to Public Interest Entities (PIEs) in the last reporting year. In accordance with the Article 36 of By-Law, transparency reports should include the following:

a) A description of the legal structure and ownership;

b) A description of key management of the audit firm

c) Where the audit firm belongs to a network, a description of the network and the legal and structural arrangement in the network;

d) A description of the related audit firms

e) A description of the organisation structure of the audit firm

f) An indication of when the last quality assurance review took place;

g) A list of public interest entities for which the audit firm has carried out statutory audits during the preceding financial year

h) A statement on the policy followed by the audit firm concerning the continuing education of statutory auditors

i) A statement concerning the audit firm's independence practices, which also confirms that an internal review of independence compliance has been conducted;

j) Distribution of revenue based on service provided as auditing, and non-auditing services.

k) Information concerning the basis for the partners' remuneration.

1) A description of the internal quality control system of the audit firm and a statement by the administrative or management body on the effectiveness of its functioning;

m) Other information required by Public Oversight Accounting and Auditing Standards Authority (KGK).

\section{Analysis of Transparency of Audit Firms In Turkey}

In the study, transparency reports of Turkish audit firms were examined. Transparency reports of 128 audit firms were downloaded from Public Oversight Accounting and Auditing Standards Authority (KGK) web site. Out of 128 audit firms, 88 audited Public Interest Entities (PIEs) entities in 2016. According to Independent Audit ByLaw, 88 audit firms are responsible to publish transparency report until March 31,2017. Therefore the analysis of study comprises 88 transparency reports which are published in 2017.

Before the amendment of Independent Audit By-Law, audit firms were publishing transparency reports voluntarily. As shown in Table 1, before 2013, only a few audit firms were reporting their transparency reports on their website. In 2013, the number of audit firms that reported transparency report was increased drastically.

Table 1: Number of Transparency Reports in Turkey

\begin{tabular}{|l|c|}
\hline Year & $\begin{array}{l}\text { Number of } \\
\text { Reports }\end{array}$ \\
\hline 2008 & 2 \\
\hline 2009 & 7 \\
\hline 2010 & 7 \\
\hline 2011 & 7 \\
\hline 2012 & 8 \\
\hline 2013 & 60 \\
\hline 2014 & \\
\hline
\end{tabular}




\begin{tabular}{|l|c|}
\hline 2015 & 74 \\
\hline 2016 & 86 \\
\hline 2017 & 88 \\
\hline
\end{tabular}

In comply with Independent Audit By-Law, each disclosure requirements of transparency reports is seperately explained below.

\section{a) A description of the legal structure and ownership}

All audit firms provided a description of their legal structure and ownership. Additionally, the majority provided further information including the number and location of offices, the amount of capital, and city of headquarter. Average capital amount of audit firms is $135.245 \mathrm{TL}$. Average number of shareholders of audit firms is 9. Table 2 represents the distibution of cities where the headquarters of audit firms were established.

\section{Table 2: City of Headquarter of Audit Firms}

\begin{tabular}{|l|c|}
\hline City & $\begin{array}{l}\text { Percentage of } \\
\text { Audit Firms }\end{array}$ \\
\hline İstanbul & $\% 85$ \\
\hline Ankara & $\% 10$ \\
\hline İzmir & $\% 4$ \\
\hline Others & $\% 1$ \\
\hline
\end{tabular}

In Turkey, in order to render independent audit service to specified firms and in specified sectors, audit firms should be licenced by related regulation bodies. Table 3 shows the percentage of audit firms which are licenced by regulation bodies.

Table 3: Regulation Body Which Audit Firm is Licenced

\begin{tabular}{|l|c|}
\hline Regulation Body & $\begin{array}{c}\text { Percentage } \\
\text { of } \\
\text { Audit Firms }\end{array}$ \\
\hline $\begin{array}{l}\text { Public Oversight Accounting and Auditing Standards Authority } \\
\text { (KGK) }\end{array}$ & $\% 100$ \\
\hline Capital Markets Board of Turkey (SPK) & $\% 66$ \\
\hline Banking Regulation and Supervison Agency (BDDK) & $\% 61$ \\
\hline Energy Market Regulatory Authority (EPDK) & $\% 49$ \\
\hline
\end{tabular}


b) A description of key management of the audit firm

The average number of key management and partner of the audit firm is 5 and 6 , respectively. $\% 98$ of the audit firms reported the name of the key managemet and $\% 92$ of the audit firms published the name of partners in their transparency reports. In addition, $\% 38$ of the firms stated the KGK registeration number of partners.

c) Where the audit firm belongs to a network, a description of the network and the legal and structural arrangement in the network;

$\% 39$ of the firms reported that they belong to an international network. Additionally, $\% 47$ of the firms that did not belong to a network stated this explicitly, and the rest of the audit firms didn't explain any information regarding this subject.

d) A description of the affiliated audit firms

$\% 32$ of audit firms explicitly stated the affiliated audit firms. On the other hand, $\% 58$ of audit firms declared that there is no affiliated audit firms. Moreover, $\% 10$ of the audit firms didn't explained any information regarding the affiliated audit firms.

e) A description of the organisation structure of the audit firm

$\% 72$ of the transparency reports include the number of auditors employed. Table 4 shows the average number of auditors classified in their title. Addiyionally, only $\% 8$ of audit firms explicitly provided a list of the names of auditors.

Table 4: Average number of auditors

\begin{tabular}{|l|c|}
\hline Title & $\begin{array}{l}\text { Average } \\
\text { Number of } \\
\text { Auditors }\end{array}$ \\
\hline Partner & 7 \\
\hline Audit Manager & 2 \\
\hline Senior Auditor & 9 \\
\hline Staff Auditor & 15 \\
\hline
\end{tabular}

f) An indication of when the last quality assurance review took place;

Almost all of the firms provided the year of last quality assurance review took place by regulators such as KGK, SPK and BDDK. However, a few of firms report an explanation about the results of review and summary of actions taken. All firms should consider providing more detailed information on the results of external monitoring 
Table 5: Explanation About the year of Last Quality Assurance Review Took Place

\begin{tabular}{|l|c|}
\hline Regulation Body & $\begin{array}{c}\text { Percentage of } \\
\text { Audit Firms }\end{array}$ \\
\hline $\begin{array}{l}\text { Public Oversight Accounting and Auditing Standards Authority } \\
\text { (KGK) }\end{array}$ & $\% 60$ \\
\hline Capital Markets Board of Turkey (SPK) & $\% 24$ \\
\hline Banking Regulation and Supervison Agency (BDDK) & $\% 5$ \\
\hline Energy Market Regulatory Authority (EPDK) & $\% 2$ \\
\hline
\end{tabular}

g) A list of public interest entities (PIEs) for which the audit firm has carried out statutory audits during the preceding financial year

The vast majority of the transparency reports comprise a list of public interest entities for which the audit firm has carried out statutory audits during the preceding financial year. On the other hand only three transparency reports have included list of other entities audited during the preceding financial year.

The average number of public interest entities is 18 . Eventough almost all companies explicitly provide a list of names of the public interet entitties, only one of them faild to provide the names of public interet entitties.

h) A statement on the policy followed by the audit firm concerning the continuing education of statutory auditors

$\% 92$ of the audit firms include a statement on the policy followed by the audit firm concerning the continuing education of statutory auditors. Moreover, $\% 77$ of audit firms provide information regarding time of education taken by auditors during 2016.

i) A statement concerning the audit firm's independence practices, which also confirms that an internal review of independence compliance has been conducted;

Whilst all firms have provided information on their independence procedures and practices the quality of the information provided is variable. $\% 26$ of audit firms failed to confirm that an internal review of independence practices had been conducted.

j) Distribution of revenue based on service provided as auditing, and non-auditing services.

Most of the audit firms provided only revenue from audit services, revenue from non-audit services and total revenue. Amongst those firms that provided financial information in greater detail, the level of analysis of fees varies considerably. Such variation makes comparisons between audit firms difficult.

Review of transparency reports reveal that average revenue from audit services, revenue from non audit services and total revenue are 6.291.332, 2.968.533 and 9.259.865, respectively.

k) Information concerning the basis for the partners remuneration.

All firms provided information about the basis for the remuneration of partners. Almost all firms state that remuneration of partners include a semi-fixed salary element and a profit share.

l) A description of the internal quality control system of the audit firm and a statement by the administrative or management body on the effectiveness of its functioning;

This section is the most informative in the transparency reports of most firms. Highly detailed disclosures are provided by most firms under each of the component parts of their quality control systems that follow the International Standard for Quality Control (ISQC1). On the other hand, only \%36 of reports included confirmation that the firm's management was satisfied with the operation of their internal quality control system.

m) Other information required by Public Oversight Accounting and Auditing Standards Authority (KGK) 
The information provided under this section is variable. During examination of transparancy reports; it is realized that employment policy, web site of the audit firm and insurance are the main topics discussed under this section.

\section{Conclusion}

Based on the content analysis of 88 transparency reports, it is concluded that there are some areas that should be improved. During the examination, it is realized that only three of audit firms provided the list of all audited companies. It would be more informative if audit firms report the names of other audited companies besides Public Interest Entities (PIEs). In addition to that, only a few transparency reports include a statement which confirms that an internal review of independence compliance has been conducted. The level of transparency in these areas should be improved in the future. Moreover, none of the firms provided key financial indicators or ratios such as net income, ROA, gross profit etc. All firms should consider providing detail on their key performance indicators. Furthermore, most of the companies provided the year of last quality assurance review, but details and results of last quality assuance was not existing. I would recommend that firms provide greater clarity in the area of quality assurance review in future reports.

\section{References}

Amirul S. M., Salleh M. F.M \&Bakar M.A.A. B. (2015). Audit firm governance: an overview from Malaysia, Procedia Economics and Finance, 31, 632-639.

Australian Government Federal Register of Legislation (2012) Corporations Legislation Amendment (Audit Enhancement) Act 2012, https://www.legislation.gov.au/Details/C2012A00072

Colar M. (2014). Transparency of audit firms in Croatia, World Academy of Science, Engineering and Technology International Journal of Economics and Management Engineering, Vol.8, No.3, 694-698.

Colar M. (2017).Transparency report delay and disclosure by Crotian audit firms, Croatioan Operational Research Review, 8, 299-316.

Deumes, R., Schelleman, C., Bauwhede, H.V. and Vanstraelen, A. (2012), "Audit firm governance:do transparency reports reveal audit quality?", Auditing: A Journal of Practice and Theory, Vol. 31 No. 4, pp. 193-214.

Girdhar S. \& Jeppesen K. K. (2019) Practice variation in big-4 transparency reports, Accounting, Aluditing \& Accountability Journal Vol.31, No.1, 261-285.

European Union, Directive 2006/43/EC of the European Parliament and of the Counc1l of 17 May 2006 On Statutory Audits Of Annual Accounts And Consolidated Accounts, Amending Council Directives 78/ 660/EEC and 83/349/EEC and repealing Council Directive 84/253/EEC, Official Journal of the European Union, Article $40 . \quad$ https://eur-lex.europa.eu/legalcontent/EN/TXT/PDF/?uri=CELEX:32006L0043\&from=en

Kamu Gozetimi Kurumu (KGK), Bagimsiz Denetim Yonetmeligi (2012) , http://www.kgk.gov.tr/Portalv2Uploads/files/Duyurular/v2/Mevzuat/BDY/Guncel\%20BDY.pdf

Pivac S.\& Cular M. (2012). quality index creating and analysis of the transparency of audit firms-case study in Croatia, Croatioan Operational Research Review, Vol. 3, 224-235.

Pott C., Theodore J. M. \& Christoph W. (2008). The effect of a transparency report on auditor independence: practitioners' self-assessment, Review of Managerial Science, 2, 111-127.

Yi F., Elizabeth C. \& Roger S. (2015). Transparency report disclosure by Australian audit firms and opportunities for research, Manageraial Auditing Journal, Vol. 30, No.8/9, 870-910. 